University of Nebraska - Lincoln

DigitalCommons@University of Nebraska - Lincoln

USDA National Wildlife Research Center - Staff Publications
U.S. Department of Agriculture: Animal and Plant Health Inspection Service

March 1999

\title{
METHODS FOR THE DIAGNOSIS OF ACUTE 3-CHLORO- $p$-TOLUIDINE HYDROCHLORIDE POISONING IN BIRDS AND THE ESTIMATION OF SECONDARY HAZARDS TO WILDLIFE
}

John J. Johnston

USDA/APHIS/WS/National Wildlife Research Center, Analytical Chemistry Project

Daniel B. Hurlbut

USDA/APHIS/WS/National Wildlife Research Center, Analytical Chemistry Project

Michael L. Avery

USDA/APHIS/WS/National Wildlife Research Center, michael.I.avery@aphis.usda.gov

Jack C. Rhyan

USDA/APHIS/VS/National Wildlife Research Center

Follow this and additional works at: https://digitalcommons.unl.edu/icwdm_usdanwrc

Part of the Environmental Sciences Commons

Johnston, John J.; Hurlbut, Daniel B.; Avery, Michael L.; and Rhyan, Jack C., "METHODS FOR THE DIAGNOSIS OF ACUTE 3-CHLORO-p-TOLUIDINE HYDROCHLORIDE POISONING IN BIRDS AND THE ESTIMATION OF SECONDARY HAZARDS TO WILDLIFE" (1999). USDA National Wildlife Research Center Staff Publications. 537.

https://digitalcommons.unl.edu/icwdm_usdanwrc/537

This Article is brought to you for free and open access by the U.S. Department of Agriculture: Animal and Plant Health Inspection Service at DigitalCommons@University of Nebraska - Lincoln. It has been accepted for inclusion in USDA National Wildlife Research Center - Staff Publications by an authorized administrator of DigitalCommons@University of Nebraska - Lincoln. 


\title{
METHODS FOR THE DIAGNOSIS OF ACUTE 3-CHLORO-p-TOLUIDINE HYDROCHLORIDE POISONING IN BIRDS AND THE ESTIMATION OF SECONDARY HAZARDS TO WILDLIFE
}

\author{
John J. Johnston, ${ }^{*} \dagger$ Daniel B. Hurlbut, $\dagger$ Michael L. Avery $\ddagger$ and Jack C. Rhyan \\ †USDA/APHIS/WS/National Wildlife Research Center, Analytical Chemistry Project, 4101 LaPorte Avenue, Fort Collins, Colorado 80521-2154 \\ ¥USDA/APHIS/WS/National Wildlife Research Center, Florida Field Station, 2820 East University Avenue, Gainesville, Florida 32641

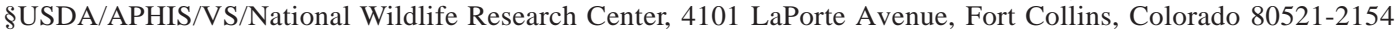

(Received 27 October 1998; Accepted 1 March 1999)

\begin{abstract}
Female boat-tailed grackles poisoned with 3-chloro- $p$-toluidine hydrochloride (CPTH) were analyzed by necropsy and gas chromatography-mass spectrometry (GC-MS). The necropsies identified the presence of a white precipitate in the pericardium, which had been previously reported as a characteristic of CPTH-exposed birds. The GC-MS method, which utilized deuterated CPTH as a surrogate, quantified CPTH residues in the breast tissue and gastrointestinal tract of CPTH-exposed birds. Comparison of these techniques indicated that the GC-MS method was more accurate for assessing CPTH poisoning in birds. Regression analyses of consumption versus residue data indicated that the sum of breast and gastrointestinal residues can be used as an estimator of $\mathrm{CPTH}$ exposure. Comparison of CPTH residues in grackles with toxicity data for a variety of scavenger and predator species provided risk quotients of less than 0.1 . Analysis of these data suggests that secondary hazards associated with the use of CPTH as an avicide for the control of pest birds are minimal.
\end{abstract}

Keywords-Secondary hazard Mass spectrometry Necropsy DRC-1339 3-Chloro- $p$-toluidine hydrochloride

\section{INTRODUCTION}

The avicide 3-chloro- $p$-toluidine hydrochloride (CPTH) (DRC-1339) is used to reduce populations of pest birds and related bird damage to a variety of agricultural crops. 3Chloro- $p$-toluidine hydrochloride is used to reduce blackbird damage to rice in the southern United States and sunflowers in the northern United States, grackle damage to citrus in Texas, and bird consumption and contamination in feed lots in a variety of livestock producing states. 3-Chloro- $p$-toluidine hydrochloride is also used around airports to control pest bird populations that threaten human safety, to manage pigeon (Columba livia) populations that pose human health concerns, and to reduce populations of gulls that prey on endangered or threatened coastal bird species (J.F. Glahn et al., unpublished data) [1-3].

Exposure to lethal doses of CPTH is assumed to cause nephrotoxicity and is associated with the deposition of a white residue containing uric acid around the heart and liver of birds [4]. The presence of this white deposit as determined by necropsy is often used as evidence of CPTH-induced toxicity in cases involving suspected illegal use of or accidental exposure to CPTH (E.W. Shafer, personal communication) [5]. To develop a more accurate assessment of CPTH exposure, a method to quantify CPTH residues in bird carcasses was developed at the National Wildlife Research Center [6]. However, method development and validation used only laboratory CPTH-fortified tissues. In this study, this residue method was used to quantify incurred CPTH residues in birds

* Author to whom correspondence should be addressed (john.j.johnston@usda.gov).

Mention of products is for identification purposes only and does not constitute endorsement by the U.S. Department of Agriculture. that consumed a wide range of lethal doses of CPTH. Performing necropsies on these CPTH-dosed birds permitted the comparison of the necropsy and the residue techniques for forensic analyses in birds ingesting a wide range of doses and exhibiting a range of postdosing times to death. Finally, comparison of the CPTH residues with CPTH toxicity data for species potentially consuming CPTH-exposed birds permitted the estimation of secondary hazards to nontarget species.

\section{METHODS AND MATERIALS}

In life

Thirty-six boat-tailed grackles (Quiscalus major) were randomly assigned to testing cages. Birds were permitted to acclimate to the test cages for $4 \mathrm{~d}$, during which time they were fed commercial bird feed and water ad libitum. This was followed by 4-d pretreatment period during which the commercial bird feed was removed at $0700 \mathrm{~h}$. Two hours later, birds received a test food cup containing $50 \mathrm{~g}$ of untreated watermelon. Aluminum pans were placed under the food cups to collect spilled watermelon. After $4 \mathrm{~h}$, the food cup was removed and reweighed. Evaporative losses were determined by placing the watermelon-containing food cup in a cage with no bird. Consumed watermelon was calculated as initial weight - final weight + evaporative losses. Birds were assigned to either a treatment group (24) or control group (12) so that the mean pretreatment consumption of watermelon was approximately equal for each group.

A 1-d treatment period was initiated the following day. The same procedure was used during the treatment period except that birds assigned to the treatment group received watermelon containing $0.1 \% \mathrm{CPTH}$ during the 4 -h exposure period. Birds 
in the control group received untreated watermelon. The quantity of watermelon consumed during the treatment period was determined for each bird. Aliquots of watermelon taken before and after the treatment period were frozen and subsequently analyzed for the determination of CPTH concentration. The quantity of CPTH consumed by each bird was calculated as the mass of watermelon consumed multiplied by the CPTH concentration.

Birds were then fed commercial bird feed and water ad libitum and observed at approximately 8-h intervals for $3 \mathrm{~d}$. Dead birds were removed from cages, time to death was noted, and birds were frozen for subsequent residue and necropsy analysis.

\section{Sample preparation}

The concentration of $\mathrm{CPTH}$ in fortified watermelon was determined by the method of Tawara et al. [7]. Watermelon pulp ( $3 \mathrm{~g}$ ) was transferred to a $50-\mathrm{ml}$ polypropylene centrifuge tube and combined with $35 \mathrm{ml}$ of high-performance liquid chromatography mobile phase (65:35, acetonitrile:water, v/v). The tube was capped, mechanically shaken at high speed for $10 \mathrm{~min}$, and sonicated for $10 \mathrm{~min}$. The sample was diluted to $40 \mathrm{ml}$ with mobile phase, centrifuged at $800 \mathrm{~g}$ for $5 \mathrm{~min}$, filtered through a $0.5-\mathrm{m}$ nylon filter into an amber high-performance liquid chromatography autosampler vial, and capped. The CPTH concentration was calculated by ultraviolet (UV) absorption versus an external standard.

Grackles were analyzed for CPTH residues by the method of Hurlbut et al. [6]. Homogenized grackle breast tissue (5 g) and gastrointestinal tract $(2 \mathrm{~g})$ were fortified with a surrogate standard, deuterated CPTH $\left(\mathrm{CPTH}_{-} \mathrm{D}_{6}\right)$, at $1 \mathrm{ppm}$. The CPTH residues were converted to their free base by the addition of $\mathrm{NaCl}$-saturated $2 \mathrm{~N} \mathrm{NaOH}$. Analyte and surrogate were extracted by partitioning into hexane and subsequently concentrated by elution of the hexane extract through a silica solidphase extraction column. Analytes were recovered from the solid-phase extraction column by elution with a minimal volume of $2 \mathrm{ml} n$-butyl acetate. The CPTH and CPTH-D $\mathrm{D}_{6}$ were quantified by gas chromatography-mass spectrometry (GCMS) analysis of the final $n$-butyl acetate solution. Actual CPTH residues were determined by dividing observed $\mathrm{CPTH}$ residues by the recovery of the surrogate, CPTH-D 6 . Microsoft Excel 97 (Microsoft, Redmond, WA, USA) was used to conduct regression analyses on consumption data (quantity CPTH consumed [mg] or dose CPTH consumed $[\mathrm{mg} / \mathrm{kg}]$ ) versus residue data (tissue residue [mg/tissue] or tissue concentration [mg/ $\mathrm{kg}]$ ).

Before the GC-MS analyses, the grackles were necropsied to determine the presence of and subjectively quantify white deposits, previously reported to contain small amounts of uric acid [5], in the body cavity of CPTH-dosed grackles. The presence of this white deposit, which occurs mainly around the heart and liver, is used as an indicator of CPTH poisoning in birds [5]. In this study, before GC-MS analysis, the grackles were necropsied to subjectively determine the amount of deposit present. The quantity of material in the body cavity of each bird was assigned one of the following ratings: normal (no residue noted), trace, 1, 2, or 3 (highest). The necropsies were performed without the knowledge of whether the birds had been exposed to CPTH.

\section{Instrumentation}

Watermelon extracts were analyzed on a Hewlett Packard 1090 M high-performance liquid chromatograph (Palo Alto,
CA, USA) equipped with a UV diode array detector $(240 \mathrm{~nm})$ and a Keystone (Bellefonte, PA, USA) Octyl $\mathrm{H}$ analytical column $(250 \times 4.6 \mathrm{~mm})$ and guard column $(15 \times 3.0 \mathrm{~mm})$. Injection volumes were $10 \mathrm{ml}$, mobile phase was acetonitrile: water $(65: 35, \mathrm{v} / \mathrm{v})$ at a flow rate of $1 \mathrm{ml} / \mathrm{min}$. Column oven was maintained at $40^{\circ} \mathrm{C}$. Run times were $8.0 \mathrm{~min}$.

Grackle body tissue extracts were analyzed with a Hewlett Packard 5890 gas chromatograph coupled to a 5970 mass selective detector. Analytes were separated on a DB-1 (J\&W Scientific, Folsom, CA USA) $30 \mathrm{~m} \times 0.25$-mm inner diameter, 0.25-m film thickness capillary column using the following temperature program: $90^{\circ} \mathrm{C}$ for $0.25 \mathrm{~min}$, increase to $300^{\circ} \mathrm{C}$ at $35^{\circ} \mathrm{C} / \mathrm{min}$. Injection port and transfer line temperatures were 280 and $300^{\circ} \mathrm{C}$, respectively. Ionization was by electron impact $(70 \mathrm{eV})$. Spectra were collected by selective ion monitoring $m / z=106,140$, and 141 for CPTH and 112, 147, and 149 for $\mathrm{CPTH}-\mathrm{D}_{6}$.

\section{RESULTS AND DISCUSSION}

The analytical methodology for avian tissue was validated by fortifying control pigeon breast and gastrointestinal tract with $\mathrm{CPTH}$ at $0,0.1,0.5$, and $2 \mathrm{mg} / \mathrm{kg}$. Recoveries ranged from 95 to $101 \%$ with relative standard deviations of 1.7 to $5.9 \%$. The method limit of detection for both tissue matrices was estimated to be $0.03 \mathrm{mg} / \mathrm{kg}$. Comparable results were observed when control grackle breast and gastrointestional tract were fortified at $0.5 \mathrm{mg} / \mathrm{kg}$ and extracted during each sample run. In addition to being adequately sensitive, this analytical method is well suited for the analysis of typically variable field samples where variable sample composition contributes to variability in analyte recovery. By adding CPTH$\mathrm{D}_{6}$ to every sample, the recoveries of incurred residues can be accurately corrected for each sample. Bound or nonextractable residues are generally assumed to pose much less toxicologic risk than extractable residues.

The watermelon methodology was validated by fortifying control watermelon with CPTH at $0.0025,0.05,0.15$, and $0.25 \%$. Recoveries ranged from 99.8 to $102 \%$ with relative standard deviations of 0.7 to $5.1 \%$. The method limit of detection was estimated to be $0.9 \mathrm{mg} / \mathrm{kg} \mathrm{CPTH}$ in watermelon pulp.

The residue analyses and necropsy results are presented in Table 1 . These analyses indicated that total residue (gastrointestinal residue + breast residue) was the best predictor of exposure (mg CPTH consumed). Coefficients of determination for these relationships ranged from 0.25 to 0.61 . The coefficient of determination for CPTH consumed versus total residue was 0.61 . The regression equation can be used to estimate $\mathrm{CPTH}$ consumption based on the results of the residue analyses: $\mathrm{mg}$ CPTH consumed $=2.7(\mathrm{mg} \mathrm{CPTH}$ total residue $)+$ 3.3 .

The residue method provided a better assessment of $\mathrm{CPTH}$ ingestion than did necropsy (Table 1). Of the 21 birds consuming lethal doses of $\mathrm{CPTH}$, the residue method detected CPTH residues in 17 birds (81\%), whereas necropsy indicated pericardium deposits in 11 birds $(52 \%)$.

All birds that consumed doses greater than $4.22 \mathrm{mg}(0.04$ $\mathrm{mg} / \mathrm{kg}$ ) died in less than $17 \mathrm{~h}$ postdosing. 3-Chloro- $p$-toluidine hydrochloride was detected in the breast muscle and gastrointestinal tracts of all these birds. The necropsy results indicated the presence of a white residue in 8 of the 16 birds that died in less than $17 \mathrm{~h}$ postdosing. For birds consuming CPTH at doses leading to death in less than $17 \mathrm{~h}$, the chemistry 
Table 1. 3-Chloro-p-toluidine hydrochloride (CPTH) residues and necropsy results

\begin{tabular}{|c|c|c|c|c|c|c|c|c|}
\hline $\begin{array}{l}\text { CPTH } \\
\text { consumed } \\
(\mathrm{mg})\end{array}$ & $\begin{array}{c}\text { Dose } \\
\text { CPTH } \\
(\mathrm{mg} / \mathrm{kg})\end{array}$ & $\begin{array}{l}\text { Hours } \\
\text { to death }\end{array}$ & $\begin{array}{l}\text { Total } \\
\text { residue } \\
(\mathrm{mg})\end{array}$ & $\begin{array}{l}\text { Breast } \\
\text { residue } \\
(\mathrm{mg})\end{array}$ & $\begin{array}{l}\mathrm{GI}^{\mathrm{a}} \text { tract } \\
\text { residue } \\
(\mathrm{mg})\end{array}$ & $\begin{array}{l}\text { Breast } \\
\text { residue } \\
(\mathrm{ppm})\end{array}$ & $\begin{array}{l}\text { GI tract } \\
\text { residue } \\
(\mathrm{ppm})\end{array}$ & $\begin{array}{l}\text { Necropsy } \\
\text { results }^{\mathrm{b}}\end{array}$ \\
\hline 93.41 & 863 & 17 & 13.68 & 7.24 & 6.44 & 0.46 & 0.75 & Normal \\
\hline 43.50 & 412 & 17 & 11.97 & 8.08 & 3.89 & 0.55 & 0.41 & Normal \\
\hline 43.17 & 394 & 17 & 13.06 & 4.77 & 8.30 & 0.37 & 0.96 & Trace \\
\hline 30.88 & 317 & 17 & 13.33 & 5.32 & 8.01 & 0.61 & 0.90 & Trace \\
\hline 21.07 & 187 & 17 & 2.42 & 1.36 & 1.07 & 0.07 & 0.14 & Normal \\
\hline 23.03 & 211 & 17 & 9.08 & 5.25 & 3.83 & 0.36 & 0.38 & 1 \\
\hline 23.50 & 251 & 17 & 10.02 & 3.75 & 6.26 & 0.29 & 0.67 & Trace \\
\hline 22.55 & 221 & 17 & 13.14 & 6.95 & 7.20 & 0.53 & 0.95 & Normal \\
\hline 26.54 & 259 & 17 & 5.24 & 0.97 & 4.26 & 0.07 & 0.46 & Normal \\
\hline 14.08 & 135 & 17 & 4.08 & 0.89 & 3.19 & 0.08 & 0.24 & Normal \\
\hline 9.66 & 98 & 17 & 1.53 & 0.54 & 0.69 & 0.07 & 0.72 & 1 \\
\hline 8.25 & 81 & 17 & 1.54 & 0.84 & 0.69 & 0.06 & 0.72 & 1 \\
\hline 7.57 & 69 & 17 & 0.72 & 0.72 & 0.00 & 0.04 & 0.00 & 2 \\
\hline 7.16 & 68 & 17 & 3.49 & 3.49 & 0.00 & 0.233 & 0.00 & 3 \\
\hline 6.02 & 56 & 17 & 4.34 & 2.18 & 2.16 & 0.15 & 0.35 & Normal \\
\hline 4.22 & 40 & 17 & 2.06 & 1.01 & 2.06 & 0.71 & 0.10 & Normal \\
\hline 2.28 & 22 & 60 & 0.00 & 0.00 & 0.00 & 0.00 & 0.00 & Normal \\
\hline 2.14 & 22 & 41 & 0.00 & 0.00 & 0.00 & 0.00 & 0.00 & Normal \\
\hline 1.91 & 17 & 26 & 0.73 & 0.72 & 0.00 & 0.05 & 0.00 & 3 \\
\hline 0.31 & 3 & 21 & 0.00 & 0.00 & 0.00 & 0.00 & 0.00 & 1 \\
\hline Trace & 0 & 65 & 0.00 & 0.00 & 0.00 & 0.00 & 0.00 & 3 \\
\hline
\end{tabular}

${ }^{\mathrm{a}} \mathrm{GI}=$ gastrointestinal.

${ }^{\mathrm{b}}$ Ratings of the quantity of deposits in the body cavity. Normal $=$ no residue noted; $3=$ highest rating.

residue method correctly indicated CPTH exposure in all cases, whereas the necropsy approach correctly indicated CPTH exposure in only $50 \%$ of these birds.

Both the chemical analysis and necropsy methods inaccurately determined CPTH exposure in birds exposed to less than $2.28 \mathrm{mg} \mathrm{CPTH}$. For the five birds that consumed lower doses of CPTH, death was noted 21 to $65 \mathrm{~h}$ postdosing. 3Chloro- $p$-toluidine hydrochloride residues were detected in only one of these birds, whereas the necropsy results indicated pericardium deposits in three birds.

Three birds in the treatment group did not consume the CPTH watermelon. These three birds survived for the duration of the experiment. No CPTH residues were detected in these birds or in any of the control birds. Similarly, the necropsies were negative for these surviving birds also.

In this study, acute doses for grackles ranged from 3 to 863 $\mathrm{mg} / \mathrm{kg}$. The reported LD50s for the starling (Sturnis vulgaris) (3.2 mg/kg), mourning dove (Zenaida macroura) $(3.1 \mathrm{mg} / \mathrm{kg})$, northern bobwhite (Colinus virginianus) (3 mg/kg), and redwinged blackbird (Agelaius phoeniceus) $(2.4 \mathrm{mg} / \mathrm{kg}$ ) suggest that similar toxicity would have been observed in all these species. The mallard (Anas platyrhynchos) (105 mg/kg) likely would be a bit more resistant to toxicity than the boat-tailed grackles used in this study.

The acute toxicities and risk quotients for CPTH to several avian scavengers and predators are summarized in Table 2.

Table 2. Acute oral toxicity and risk quotients of 3-chloro-p-toluidine hydrochloride (CPTH) to avian predators and scavengers and mammals

\begin{tabular}{|c|c|c|c|c|c|}
\hline Common name (species) & $\begin{array}{l}\mathrm{LD}^{2} 0^{\mathrm{a}} \\
(\mathrm{mg} / \mathrm{kg})\end{array}$ & $\begin{array}{l}\text { Average weight } \\
\text { (g) }\end{array}$ & $\begin{array}{c}\text { Ingestion rate } \\
(\mathrm{g} / \mathrm{g} / \mathrm{d})\end{array}$ & $\mu \mathrm{g}$ CPTH/g/d & Risk quotient \\
\hline Barn owl (Tyto alba) & 4.2 & $466^{b}$ & $0.15^{\mathrm{c}}$ & 0.143 & 0.034 \\
\hline Northern harrier (Circus cyaneus) & 100 & $441^{\mathrm{b}}$ & $0.19^{\mathrm{d}}$ & 0.181 & 0.0018 \\
\hline American kestrel (Falco sparverius) & 178 & $116^{\mathrm{b}}$ & $0.30^{\mathrm{e}}$ & 0.285 & 0.0016 \\
\hline Cooper's hawk (Accipiter cooperii) & 562 & $439^{b}$ & $0.20^{\mathrm{f}}$ & 0.190 & 0.0003 \\
\hline Lab rat (Rattus norvegicus) & 326 & $485^{\mathrm{g}}$ & $0.1^{\mathrm{g}}$ & 0.095 & 0.00029 \\
\hline Lab mouse (Mus musculus) & 960 & $30^{\mathrm{h}}$ & $0.15^{\mathrm{h}}$ & 0.143 & 0.00015 \\
\hline Deer mouse (Peromyscus maniculatus) & 1,800 & $20^{\mathrm{i}}$ & $0.22^{\mathrm{i}}$ & 0.209 & 0.00012 \\
\hline Coyote (Canis latrans) & 100 & $15,009^{\mathrm{j}}$ & $0.06^{\mathrm{k}}$ & 0.057 & 0.00057 \\
\hline Dog (Canis familiaris) & 100 & $10,000^{\mathrm{k}}$ & $0.06^{\mathrm{k}}$ & 0.057 & 0.00057 \\
\hline
\end{tabular}

a $[11-14]$.

${ }^{\mathrm{b}}[14]$.

c [15].

d $[16]$.

e [17].

$\mathrm{f}[18]$.

g Available at: http://www.uiowa.edu/ vpr/research/animal/rat_o001.htm.

${ }^{\mathrm{h}}$ Available at: http://www.uiowa.edu/ vpr/research/animal/mice0001.htm.

i $[19,20]$.

j $[21]$.

${ }^{\mathrm{k}}[22]$. 
The LD50s range from $4.2 \mathrm{mg} / \mathrm{kg}$ for the barn owl (Tyto alba) to $562 \mathrm{mg} / \mathrm{kg}$ for the Cooper's hawk (Accipiter cooperii). Most of these species have been observed to feed on CPTH-poisoned birds in a variety of pest bird control situations [8]. The LD50s for a number of mammalian species have also been reported. The LD50s for male and female rats (Rattus norvegicus) were 350 and $302 \mathrm{mg} / \mathrm{kg}$. 3-Chloro- $p$-toluidine hydrochloride seems to be less toxic to mice, as LD50s of 960 and $1,800 \mathrm{mg} / \mathrm{kg}$ have been reported for the laboratory mouse (Mus musculus) and the deer mouse (Peromyscus maniculatus), respectively. The LD50 for CPTH to coyotes (Canis latrans) and dogs (Canis familiaris) exceeded $100 \mathrm{mg} / \mathrm{kg}$.

The U.S. Environmental Protection Agency uses the quotient method for estimating pesticide exposure-related hazards to nontarget species [9]. This approach calculates a risk quotient as the ratio of the estimated daily dose or expected concentration of toxicant in a dietary constituent to the LD50 or LC50, respectively. The resulting risk quotient is compared to established levels of concern, which indicate varying levels of risk to exposed species. In general, a risk quotient less than 0.1 is considered to present acceptable risk under approved use guidelines. A risk quotient of 0.1 or greater triggers concern for endangered species and restrictions may be imposed to protect these species. A risk quotient of 0.2 or greater triggers concerns for use by uncertified pesticide applicators. The product may be restricted to only certified applicators and appropriate mitigation techniques may be imposed. A risk quotient of 0.5 or greater triggers concern for all species of the same taxonomic order and appropriate mitigation techniques may be imposed [10].

To estimate the hazard presented by grackle carcasses, a worst-case scenario was used to calculate risk quotients (Table 2 ). The fact that the caged birds could consume only CPTH watermelon baits resulted in much higher doses and risk quotients than would be expected under field conditions. Additionally, the daily diet of the nontarget species was assumed to consist solely of grackle tissue with the highest concentration of CPTH, $0.95 \mathrm{mg} / \mathrm{g}$. Although CPTH toxicity might be higher to juvenile predators or scavengers and residues might be higher during the period between consumption and death, we feel that the worst case study design more than offsets these potential variables.

The risk quotients presented in Table 2 suggest that the secondary hazards associated with $\mathrm{CPTH}$ are negligible. For avian scavengers and predators, risk quotients ranged from 0.034 for the barn owl to 0.0003 for the Copper's hawk. The CPTH LD50s for the black-billed magpie (Pica pica), common raven (Corvus corax), and the golden eagle (Aquila chrysaetos) were reported to be 10,13 , and greater than $100 \mathrm{mg} / \mathrm{kg}$, respectively [5]. Typical ingestion rates are not known for these species and risk quotients could not be estimated. However, because the toxicity and average mass of these species fall within the range of these parameters for the birds presented in Table 2, the risks of secondary poisoning are likely to be similar.

The nontarget hazards to mammalian species are even less than for birds. Although the acute toxicities of CPTH to the mammals listed in Table 2 are similar to those for birds, the lower ingestion rates for the mammals lead to lower risk quotients. These risk quotients ranged from 0.00012 for deer mice to 0.00057 for dogs and coyotes, about an order of magnitude less than those for the avian scavengers.

\section{CONCLUSION}

Gas chromatography-mass spectrometry proved to be a more reliable method than necropsy for the determination of CPTH poisoning in grackles. Neither method was acceptable for determining CPTH exposure in birds that had died more than $17 \mathrm{~h}$ after exposure. However, the low residue levels (less than $30 \mathrm{ng} / \mathrm{g}$ ) in these birds suggest that the secondary hazards to potential consumers of avian carcasses containing $\mathrm{CPTH}$ are quite low. Birds consuming higher doses of CPTH died several hours after exposure and had $\mathrm{CPTH}$ residues as high as $0.95 \mathrm{mg} / \mathrm{g}$. Consumption of these birds also poses a very low secondary hazard risk to wildlife.

Acknowledgement-We are indebted to John Humphrey for his assistance with the in-life portion of this experiment and John Eisemann for input regarding secondary hazards and technical review of this manuscript.

\section{REFERENCES}

1. Linz GM, Bergman DL. 1996. DRC-1339 avicide fails to protect ripening sunflowers. Crop Prot 15:307-310.

2. Cummings JL, Pochop PA, Garrison MV, Furcolow CA. 1994. Laboratory studies with compound DRC-1339 on feral pigeons. In Halverson WS, Crabb AC, eds, Proceedings, 16th Vertebrate Pest Conference, University of California at Davis, Davis, CA, USA, March 1-3, pp 254-274.

3. Shafer EW. 1994. DRC-1339 registrations for bird control. Proceedings, Western Region Coordinating Committee-95 Annual Meeting, Reno, NV, USA, November 16-17, p 25.

4. Kimball BA, Mishalanie EA. 1994. Stability of 3-chloro-p-toluidine hydrochloride in buffered aqueous solutions. Environ $\mathrm{Sci}$ Technol 28:419-422.

5. DeCino TJ, Cunningham DJ, Schafer EW. 1966. Toxicity of DRC1339 to starlings. JWildl Manage 30:249-253.

6. Hurlbut DB, Johnston JJ, Daniel SR, Tawara JN. A gas chromatography/mass spectrometry method for the quantitation of 3 chloro- $p$-toluidine hydrochloride $(\mathrm{CPTH})$ in birds using a deuterated surrogate. J Agric Food Chem 46:4610-4615.

7. Tawara JN, Johnston JJ, Goodall MJ. 1996. The degradation of 3 -chloro- $p$-toluidine hydrochloride in watermelon bait: Identification and chemical characterization of $\mathrm{N}$-glucoside and oxopropamine. J Agric Food Chem 44:3983-3988.

8. Savarie PJ, Schafer EW. 1986. Biodeterioration of warfarin, sodium monofluoroacetate (1080), 4-aminopyridine and 3-chloro4-methylbenzamine in terrestrial vertebrate pests. Int Biodeterior Biodegr 6:66-73.

9. Urban DJ, Cook NJ. 1986. Ecological risk assessment: Standard evaluation procedure of the Hazard Evaluation Division, Office of Pesticide Programs. EPA-540/9-85-001. U.S. Environmental Protection Agency, Washington, DC.

10. National Research Council. 1983. Risk assessment in the federal government: Managing the process. National Acadamy of Sciences, National Research Council, Washington, DC.

11. Schafer EW, Bowles WA, Hurlbut J. 1983. The acute oral toxicity, repellency and hazard potential of 998 chemicals to one or more species of wild and domestic birds. Arch Environ Contam Toxicol $12: 355-382$.

12. Shafer EW, Bowles WA. 1985. The acute oral toxicity and repellency of 933 chemicals to house and deer mice. Arch Environ Contam Toxicol 14:111-129.

13. Schafer EW. 1972. The acute oral toxicity of 369 pesticidal, pharmaceutical and other chemicals to wild birds. Toxicol Appl Pharmacol 21:315-330.

14. Dunning JB. 1994. Body weights of 686 species of North American birds. Western Bird Banding Association Monograph 1. Eldon, Cave Creek, AZ, USA.

15. Sample BE, Sutter GW. 1997. Estimating exposure of terrestrial wildlife to contaminants. Publication ES/ER/TM-125. U.S. Environmental Protection Agency, Washington, DC.

16. MacWhirter RB, Bildstein KL. 1993. Northern harrier. In Poole A, Gill F, eds, The Birds of North America, No 75. Academy of Natural Sciences, Washington, DC.

17. Johnsgard PA. 1990. Hawks, Eagles, and Falcons of North Amer- 
ica-Biology and Natural History. Smithsonian Institution, Washington, DC.

18. Rosenfeild RN, Bielefeldt J. 1993. Cooper's hawk. In Poole A, Gill F, eds, The Birds of North America, No 75. The Academy of Natural Sciences, Washington, DC.

19. U.S. Environmental Protection Agency. 1993. Wildlife Exposure Factors Handbook, Vol 1. EPA/600/R-93/187. Washington, DC.
20. U.S. Environmental Protection Agency. 1993. Wildlife Exposure Factors Handbook, Vol 2. EPA/600/R-93/187. Washington, DC.

21. Parker G. 1995. Eastern coyote-The story of its success. Nimbus, Halifax, NS, Canada.

22. Fraser CM, Mays A, eds. 1986. Merck Veterinary Manual, 6th ed. Merck Publishing Company, Rahway, NJ, USA. 